\title{
DINASTI ABBASIYAH: KEMAJUAN PERADABAN ISLAM, PENDIDIKAN DAN KEBANGKITAN KAUM INTELEKTUAL
}

\author{
Nunzairina*
}

Program Studi Sejarah Peradaban Islam, Fakultas IImu Sosial, Universitas Islam Negeri Sumatera Utara, Indonesia

\begin{abstract}
In Islamic historical literature, Baghdad is known as the center of Islamic civilization, both in the fields of science, culture and literature. The progress of this civilization presents Baghdad as a city of intellectuals, not only Arabs present, Europeans, Persians, Chinese, Indians and Africans were present to fill the atmosphere of knowledge here. It was this Abbasid caliphate that was known for growing rapidly in knowledge. At this time a lot of emerging Muslim intellectuals both in the field of science and religion. During the Abbasid Caliphate, socio-economic conditions developed well. As is the case in agriculture and trade. Society at that time was able to regulate the order of his life well, to be known as a famous and prosperous country. During the Abbasid empire Islamic power expanded. The community is divided into two groups, namely a special group and a general group, a general group consisting of artists, scholars, fuqoha, poets, merchants, businessmen, workers and farmers while the special group consists of caliphs, caliph's family, the nobles, and officials Country. In the development of science, the caliphs supported many of these developments, seen from the number of foreign language books that were translated into Arabic, and the birth of intellectuals.
\end{abstract}

Keywords: Abbasid caliphate, Baghdad, intellectuals.

\section{Abstrak}

Dalam literatur sejarah Islam, Baghdad dikenal sebagai pusat peradaban Islam, baik dalam bidang sains, budaya dan sastra. Kemajuan peradaban ini menghadirkan Baghdad sebagai kota para intelektual, tidak hanya orang arab yang hadir, bangsa Eropa, Persia, Cina, India serta Afrika turut hadir mengisi atmosfer pengetahuan disini. Masa kekhalifahan Abbasiyah ini lah yang dikenal berkembang pesatnya pengetahuan. Pada masa ini banyak sekali bermunculan intelektual-intelektual muslim baik dalam bidang ilmu pengetahuan maupun ilmu agama. Dalam masa Kekhalifahan Abbasiyah keadaaan sosial ekonomi pun berkembang dengan baik. Seperti halnya dalam bidang pertanian maupun perdagangan. Masyarakat pada masa itu mampu mengatur tatanan kehidupannya dengan baik, hingga dikenal sebagai negeri masyhur dan makmur. Pada masa Abbasiyah kekuasaan Islam bertambah luas. Masyarakat dibagi atas dua kelompok yaitu kelompok khusus dan kelompok umum, kelompok umum terdiri dari seniman, ulama, fuqoha, pujangga, saudagar, pengusaha kaum buruh, dan para petani sedangkan kelompok khusus terdiri dari khalifah, keluarga khalifah, para bangsawan, dan petugas-petugas Negara. Dalam perkembangan ilmu pengetahuan, para khalifah banyak mendukung perkembangan tersebut, terlihat dari banyaknya buku-buku bahasa asing yang diterjemahkan kedalam bahasa arab, dan lahirnya para kaum intelektual.

Kata Kunci: Dinasti Abbasiyah, Baghdad, Kaum Intelektual.

\section{PENDAHULUAN}

Berdirinya Dinasti Abbasiyah berawal sejak merapuhnya kekuasaan Bani Umayyah yang berujung pada keruntuhan Dinasti Umayah di Damaskus. Dengan segala konflik yang ada pada tubuh Bani Umayyah, menjadikankan Bani Abbasiyah maju sebagai pengganti kepemimpinan umat Islam. Wajah revolusi kepemimpinan Abbasiyah terhadap Umayyah banyak mendapatkan simpati dari masyarakat, terutama dari kalangan Syi'ah. Dukungan itu hadir disebabkan janji untuk menegakkan kembali keadilan seperti yang dipraktikkan oleh Khulafaurrasyidin (Abdurrahman, 2003, p. 118). Nama Dinasti Abbasiyah diambil dari nama salah seorang paman Nabi Muhammad yang

*Correspondance Author: nunzairina@uinsu.ac.id

Article History | Submitted: April 23, 2019 | Accepted: December 15, 2019 | Published: January 1, 2020

How to Cite (APA $6^{\text {th }}$ Edition style):

Nunzairina. (2020). Dinasti Abbasiyah: Kemajuan Peradaban Islam, Pendidikan dan Kebangkitan Kaum 
bernama al-Abbas ibn Abd al-Muthalib ibn Hisyam. Dinasti ini didirikan oleh Abdullah al-Saffah ibn Muhammad Ibn Ali Ibn Abdullah Ibn al-Abbas (Hitti, 2002, p. 395; Yatim, 2008, p. 49).

Bani Abbasiyah merasa lebih berhak dari Bani Umayyah atas Kekhalifahan Islam, sebab mereka adalah dari cabang Bani Hasyim yang secara garis keturunan lebih dekat dengan Nabi. Menurut mereka, Bani Umayyah menguasai bangku kekhalifahan Islam secara paksa, dengan melalui tragedi Perang Siffin. Oleh karena itu, untuk mendirikan Dinasti Abbasiyah, mereka mengadakan gerakan yang luar biasa melakukan pemberontakan terhadap Dinasti Umayyah (Karim, 2009, p. 143). Kekuasaan Bani Abbasiyah berlangsung selama lima abad sejak tahun 750-1258 M, melanjutkan kekuasaan Bani Umayyah.

Setelah meruntuhkan Dinasti Umayyah dengan cara membunuh Marwan sebagai khalifahnya, pada tahun $750 \mathrm{M}$, Abu al-'Abbas mendeklarasikan dirinya sebagai khalifah pertama Dinasti Abbasiyah. Ketika Abbas menjabat khalifah, dia diberi gelar al-Saffah yang berarti penumpah atau peminum darah. Sebutan tersebut diberikan karena dia mengeluarkan dekrit kepada gubernurnya yang berisi perintah untuk membunuh tokoh-tokoh Umayyah. Bukan hanya itu saja, al-Saffah juga melakukan perbuatan keji dengan menggali kuburan para khalifah Bani Umayyah (kecuali Umar II), dan tulang-tulangnya dibakar. Berdirilah sebuah Dinasti menuju kekuasaan yang bersifat internasional, dengan assimilasi corak pemikiran dan peradaban Persia, Romawi Timur, Mesir dan sabagainya. Al-Saffah menjadi pendiri Dinasti Arab Islam ketiga - setelah Khulafaurrasyidin dan Dinasti Umayyah - yang sangat besar dan berusia lama (Hitti, 2002, p. 358).

Sebelum wafat, al-Saffah mengangkat saudaranya Abu Ja'far dengan gelar alMansur (754-775) yang artinya "sultan Tuhan di atas bumi-Nya". Ialah khalifah terbesar Dinasti Abbasiyah, meskipun bukan seorang muslim yang saleh, dialah sebenarnya yang membangun Dinasti, tiga puluh lima orang khalifah berasal dari keturunannya. Madinah as-Salam, nama resmi kota al-Mansur atau Al-Mudawwarah (kota lingkaran), gerbang emas; kubah biru 'al-qubbah al-khadhra'. Al-Mansur berbadan tinggi, berkulit gelap dan berjanggut tipis, gigih dan tegas. Berbagai kebijakannya dijadikan acuan bagi para penerusnya, sebagaimana kebijakan Muawiyyah menjadi acuan bagi khalifahkhalifah Umayyah. Masa kekuasaan ini berhasil mencapai kejayaan dan kemegahan yang tidak ada tandingannya pada abad pertengahan, kecuali mungkin oleh Konstantinopel. Menjadi pewaris kekuatan dan prestise kota Ctesiphon, Babilonia, Nineceh, Ur, dan ibukota-ibukota bangsa Timur Kuno (Hitti, 2002, p. 360).

Selama 22 tahun masa kekhalifahannya, ada beberapa hal besar yang pernah dilakukannya sebagai kontribusi bagi perkembangan peradaban Islam, seperti berhasil mendapatkan sejumlah buku dari raja Bizantium termasuk karya Euclid. Namun orang Arab tidak memahami bahasa Yunani, dan pada awalnya bersandar pada terjemahan yang dibuat oleh orang yang ditaklukkannya, yaitu Yuhudi penyembah berhala, maupun orang Kristen Nestor, serta memindahkan ibukota kerajaan ke Baghdad, dan memunculkan tradisi baru yaitu menerapkan sistem wazir yang berasal dari ketatanegaraan Persia untuk membawahi suatu departemen. 
Pada masa kekhalifahan al-Mahdi ibn al-Mansur, perekonomian mulai membaik. Pertanian ditingkatkan dengan mengadakan irigasi, sehingga hasil gandum, beras, kurma dan minyak zaitun bertambah. Begitu pula dengan hasil pertambangan seperti perak, emas, tembaga, besi dan lainnya juga bertambah. Dagang transit antara Timur dan Barat membawa kekayaan. Basrah dijadikan pelabuhan yang cukup penting saat itu. Ialah khalifah pertama mengumandangkan Perang Suci melawan Bizantium, dipimpin anaknya Harun dan sukses. Selama ekspedisi inilah, ayahnya memberi gelar al-Rasyid yang artinya "pengikut jalan yang lurus". Kekhalifahan al-Mahdi digantikan oleh al-Hadi atas dasar wasiat ayah al-Mahdi. Namun kekhalifahan tersebut hanya berjalan satu tahun, dan kemudian ia digantikan oleh Harun al-Rasyid (Nizar, 2009, p. 70).

Pada masa kepemimpinan Harun al-Rasyid, masyarakat hidup cukup mewah, seperti yang digambarkan dalam hikayat "Seribu Satu Malam". Kekayaan yang banyak dipergunakan khalifah untuk kepentingan sosial. Rumah sakit didirikan, pendidikan dokter diutamakan dan farmasi di bangun. Pada saat itu, Baghdad telah mempunyai 8 oo dokter. Selain itu, Harun al-Rasyid juga mendirikan pemandian-pemandian umum, sehingga dirinya cukup terkenal pada zamannya. Lembaran sejarah abad ke-9, dua nama raja yang menguasai percaturan dunia: Charlemagne di Barat dan Harun al-Rasyid di Timur.

Pada masa khalifah Harun al-Rasyid kota Baghdad juga menjadi saingan satusatunya Bizantium. Kejayaannya berjalan seiring dengan kemakmuran kerajaan. Masuknya berbagai pengaruh asing, sebagian Indo-Persia, dan Suriah, serta yang paling penting adalah pengaruh Yunani. Gerakan intelektual itu ditandai dengan proyek penerjemahan karya-kara berbahasa Persia, Sanskerta, Suriah, dan Yunani ke bahasa Arab. Dimulai dengan karya mereka sendiri tentang ilmu pengetahuan, filsafat, atau sastra yang tidak terlalu banyak, orang Arab memiliki keingintahuan yang tinggi dan minat belajar yang besar, segera menjadi penerima dan pewaris peradaban bangsabangsa yang lebih tua dan berbudaya yang mereka taklukkan, atau yang mereka temui.

Peradaban Islam mengalami puncak kejayaan pada masa daulah Abbasiyah. Perkembangan ilmu pengetahuan sangat maju. Kemajuan ilmu pengetahuan diawali dengan penerjemahan naskah-naskah asing terutama yang berbahasa Yunani ke dalam bahasa Arab, pendirian pusat pengembangan ilmu dan perpustakaan Bait al-Hikmah, dan terbentuknya mazhab-mazhab ilmu pengetahuan dan keagamaan sebagai buah dari kebebasan berpikir. Popularitas Dinasti Abbasiyah mencapai puncaknya di zaman khalifah Harun al-Rasyid (786- 8o9 M) dan puteranya al-Ma'mun (813-833 M). Kekayaan yang banyak dimanfaatkan Harun al-Rasyid untuk keperluan sosial; rumah sakit, lembaga pendidikan, dokter, dan farmasi didirikan (Syukur, 2009, p. 98).

Sejak upaya penerjemahan meluas dan sekaligus sebagai hasil kebangkitan ilmu pengetahuan, banyak kaum muslimin mulai mempelajari ilmu-ilmu itu langsung dalam bahasa Arab sehingga muncul sarjana-sarjana muslim yang turut mempelajari, mengomentari, membetulkan buku-buku penerjemahan atau memperbaiki atas kekeliruan pemahaman kesalahan pada masa lampau, dan menciptakan pendapat atau ide baru, serta memperluas penyelidikan ilmiah untuk mengungkap rahasia alam, yang dimulai dengan mencari manuskrip-manuskrip klasik peninggalan ilmuwan Yunani 
kuno, seperti karya Aristoteles, Plato, Socrates, dan sebagainya. Manuskrip-manuskrip tersebut kemudian dibawa ke Baghdad lalu diterjemahkan dan dipelajari di perpustakaan yang merangkap sebagai lembaga penelitian al-Baitul Hikmah, sehingga melahirkan pemikiran-pemikiran baru.

Sejak akhir abad ke-10, muncul sejumlah tokoh wanita dibidang ketatanegaraan dan politik seperti, Khaizura, Ullayyah, Zubaidah, dan Bahrun. Di bidang kesusasteraan dikenal Zubaidah dan Fasl. Di bidang sejarah, para ahli sejarah Arab mulai menyelidiki sejarah mereka sendiri, baik beberapa peninggalan yang sudah kabur, maupun hanya merupakan penggalan cerita, ataupun yang sudah tertulis dalam bentuk yang sudah disetujui dan cenderung buah daripada sekte keagamaan yang bermacam-macam. Penulisan dan penyusunan sejarah dalam ukuran besar didorong oleh paradigma orangorang Persia. Seperti Pahlevi Khuday Namich yang menuliskan sejarah-sejarah raja, dan diterjemahkan oleh Ibn al-Muqaffa'dari bahasa Persia kuno ke dalam bahasa Arab dengan judul Persia (Turkish Muluk al-'Ajam). Buku ini dianggap sebagai paradigma penulisan sejarah. Hisham dari suku Kalb (619 M) dan ayah Muhammad merupakan ahli sejarah bangsa Arab pertama, mereka terkenal karena ketelitian dalam ceritanya (Hasan, 1989, p. 135). Di bidang kehakiman, muncul Zainab Umm al-Muwayid. Di bidang seni musik, Ullayyah dikenal sangat tersohor pada waktu itu.

Berdasarkan fakta sejarah, sebanyak 37 khalifah yang pernah menjadi pemimpin pada masa kekuasaan Bani Abbasiyah, dan masa keemasannya dimuali antara masa khalifah ketiga al-Mahdi, dan khalifah hingga ke sembilan, al-Watsiq, dan khususnya pada masa Harun al-Rasyid dan anaknya al-Makmun. Setelah itu Dinasti Abbasiyah mulai mengalami penurunan dan pada akhirnya runtuh.

\section{HASIL DAN PEMBAHASAN}

\section{Abbasiyah sebagai Pusat Peradaban dan Pendidikan}

Kota Baghdad didirikan oleh Khalifah Abbasiyah kedua, al-Manshur (754-775 M) pada tahun $762 \mathrm{M}$. setelah mencari-cari daerah yang strategis untuk ibukotanya, pilihan jatuh pada daerah yang sekarang dinamakan Baghdad, terletak di pinggir sungai Tigris. Al-Mansur sangat cermat dan teliti dalam masalah lokasi yang akan dijadikan ibukota. Ia menugaskan beberapa orang ahli untuk meneliti dan mempelajari lokasi. Bahkan, ada beberapa orang di antara mereka yang diperintahkan tinggal beberapa hari di tempat itu pada setiap musim yang berbeda, kemudian para ahli tersebut melaporkan kepadanya tentang keadaan udara, tanah dan lingkungan.

Dalam pembangunan kota ini, khalifah memperkenalkan ahli bangunan yang terdiri dari arsitektur-arsitektur, tukang batu, tukang kayu, ahli lukis, ahli pahat dan lain-lain. Mereka didatangkan dari Syiria, Mosul, Basrah dan Kufah yang berjumlah sekitar 100.000 orang. Kota ini berbentuk bundar. Di sekelilingnya dibangun dinding tembok yang besar dan tinggi. Di sebelah luar dinding tembok, digali parit besar yang berfungsi sebagai saluran air dan sekaligus sebagai benteng. Ada empat buah pintu gerbang di seputar kota ini, disediakan untuk setiap orang yang ingin memasuki kota. Keempat pintu gerbang itu adalah Bab al-Kufah, terletak di sebelah baratdaya, Bab alSyam di baratlaut, Bab al-Bashrah di tenggara, dan Bab al-Khurasan di timurlaut. Di antara masing-masing pintu gerbang ini, dibangun 28 menara sebagai tempat pengawal 
Negara yang bertugas mengawasi keadaan di luar. Di atas setiap pintu gerbang dibangun suatu tempat peristirahatan yang dihiasi dengan ukiran-ukiran yang indah dan menyenangkan.

Sejak awal berdirinya, kota ini sudah menjadi pusat peradaban dan kebangkitan ilmu pengetahuan dalam Islam. Itulah sebabnya, Philip K. Hitti menyebutnya sebagai kota intelektual. Menurutnya, di antara kota-kota dunia, Baghdad merupakan professor masyarakat Islam. Al-Mansur memerintahkan penerjemahan buku-buku ilmiah dan kesusastraan dari bahasa asing: India, Yunani, Bizantium, Persia, dan Syiria. Para peminat ilmu dan kesusastraan segera berbondong-bondong datang ke kota ini (Hitti, 2002, p. 369).

Setelah masa al-Mansur, kota Baghdad menjadi lebih masyhur lagi karena perannya sebagai pusat perkembangan peradaban dan kebudayaan Islam. Banyak para ilmuwan dari berbagai daerah datang ke kota ini untuk mendalami ilmu pengetahuan. Masa keemasan kota Baghdad terjadi pada zaman pemerintahan Khalifah Harun alRasyid (786-809 M) dan anaknya al-Makmun (813-833 M). Dari kota inilah memancar sinar kebudayaan dan peradaban Islam ke seluruh dunia. Prestise politik, supremasi ekonomi, dan aktivitas intelektual merupakan tiga keistimewaan kota ini. Kebesarannya tidak terbatas pada negeri Arab, tetapi meliputi seluruh negeri Islam. Baghdad ketika itu menjadi pusat peradaban dan kebudayaan yang tertinggi di dunia. Ilmu pengetahuan dan sastra berkembang sangat pesat. Banyak buku filsafat yang sebelumnya dipandang sudah "mati" dihidupkan kembali dengan diterjemahkan ke dalam bahasa Arab. Khalifah al-Makmun memiliki perpustakaan yang dipenuhi dengan buku-buku ilmu pengetahuan. Perpustakaan itu benama Bait al-Hikmah.

Bait al-Hikmah merupakan perpustakaan yang juga berfungsi sebagai pusat pengembangan ilmu pengetahuan. Institusi ini merupakan kelanjutan dari institusi serupa di masa imperium Sasania Persia yang bernama Jundishapur Academy. Namun, berbeda dari institusi pada masa Sasania yang hanya menyimpan puisi-puisi dan ceritacerita untuk raja, pada masa Abbasiyah, institusi ini diperluas penggunaannya. Pada masa Harun al-Rasyid, institusi bernama Khizanah al-Hikmah (Khazanah kebijaksanaan) yang berfungsi sebagai perpustakaan dan pusat penelitian. Sejak $815 \mathrm{M}$, al-Ma'mun mengembangkan lembaga ini dan diubah namanya menjadi Bait al-Hikmah. Pada masa ini, Baitul Hikmah dipergunakan secara lebih maju yaitu sebagai tempat penyimpanan buku-buku kuno yang didapat dari Persia, Bizantium, dan bahkan Ethiopia dan India. Di institusi ini, al-Ma'mun mempekerjakan Muhammad ibn Musa al-Khawarizmi yang ahli dibidang aljabar dan astronomi.

Direktur perpustakaan Bait al-Hikmah sendiri adalah seorang nasionalis Persia dan ahli Pahlevi, Sahl ibn Harun. Di bawah kekuasaan al-Ma'mun, Baitul Hikmah tidak hanya berfungsi sebagai perpustakaan tetapi juga sebagai pusat kegiatan studi dan riset astronomi dan matematika. Sejak pertengahan abad ke-9, Bait al-Hikmah dikuasai oleh satu mazhab penerjemah di bawah bimbingan Hunayn ibn Ishaq. Mereka menerjemahkan karya-karya keilmuan dari Galen serta karya-karya filsafat dan metafisika Aristoteles dan Plato. Di Baitul Hikmah terdapat juga observatorium astronomi untuk meneliti perbintangan (Abdurrahman, 2003, pp. 103-105). 
Sejak awal berdirinya, kota ini sudah menjadi pusat peradaban dan kebangkitan ilmu pengetahuan dalam Islam. Sebagai pusat intelektual, di Baghdad terdapat beberapa pusat aktivitas pengembangan ilmu. Di antaranya adalah Bait al-Hikmah, yaitu lembaga ilmu pengetahuan yang menjadi pusat pengkajian berbagai ilmu. Selain itu Baghdad juga sebagai pusat penerjemahan buku-buku dari berbagai cabang ilmu ke dalam bahasa Arab. Selain itu, banyak berdiri akademi, sekolah tinggi dan sekolah biasa yang memenuhi kota itu. Dua di antaranya yang terpenting adalah perguruan Nizhamiyyah, didirikan oleh Nizham Al-Mulk, wazir Sultan Seljuk, pada abad ke-5 H dan perguruan Mustansiriyah, didirikan dua abad kemudian oleh Khalifah Mustanshir Billah (Yatim, 2008, p. 281).

Dalam bidang sastra, kota Baghdad terkenal dengan hasil karya yang indah dan digemari orang. Di antara karya sastra yang terkenal ialah Alf Lailah wa Lailah, atau kisah seribu satu malam. Di kota Baghdad ini, lahir dan muncul para saintis, ulama, filofof, dan sastrawan Islam yang terkenal, seperti al-Khawarizmi (ahli astronomi dan matematika, penemu ilmu aljabar), al-Kindi (filosof Arab pertama), al-Razi (filosof, ahli fisika dan kedokteran), al-Farabi (filosof besar yang dijuluki dengan al-Mu'allim alTsani, guru kedua setelah Aristoteles), tiga pendiri madzhab hukum Islam (Abu Hanifah, Syafi'i, dan Ahmad ibn Hambal), al-Ghazali (filosof, teolog, dan sufi besar dalam Islam yang dijuluki dengan Hujjah al-Islam), Abd al-Qadir al-Jailani (pendiri tarekat Qadariyah), Ibn Muqaffa' (sastrawan besar) dan lain-lain. Dalam bidang ekonomi, perkembangannya berjalan seiring dengan perkembangan politik. Pada masa Harun al-Rasyid dan al-Makmun, perdagangan dan industri berkembang pesat. Kehidupan ekonomi kota ini didukung oleh tiga buah pelabuhan yang ramai dikunjungi para kafilah dagang internasional, yang menyebabkan Abbasiyah menjadi salah satu kota termahsyur pada masa sejarah peradaban Islam (Majalah As-Sunnah Edisi 7 Tahun $\mathrm{XV} 1432 \mathrm{H} / 2011$ ).

\section{Lembaga Pendidikan Pada Masa Dinasti Abbasiyah}

Pada masa Dinasti Abbasiyah, pendidikan dan pengajaran berkembang dengan sangat pesat sehingga anak-anak bahkan orang dewasa saling berlomba dalam menuntut ilmu pengetahuan. Tingginya nilai pendidikan dalam kehidupan, menyebabkan mayoritas masyarakat meninggalkan kampung halaman mereka, demi untuk mendapatkan ilmu pengetahuan di kota, dan salah satu indikator berkembang pesatnya pendidikan dan pengajaran ditandai dengan tumbuh dan berkembangnya lembaga-lembaga pendidikan Islam.

Dalam dunia Islam sebelum munculnya lembaga pendidikan formal, masjid dijadikan sebagai pusat pendidikan. Fungsi masjid selain untuk tempat menunaikan ibadah juga dijadikan sarana dan fasilitas untuk pendidikan, di antaranya tempat pendidikan anak-anak, tempat-tempat pengajian dari ulama-ulama yang merupakan kelompok-kelompok (halaqah), tempat untuk berdiskusi dan munazharah dalam berbagai ilmu pengetahuan, dan juga dilengkapi dengan ruang perpustakaan yang berisikan buku-buku dari berbagai macam ilmu pengetahuan yang cukup banyak.

Selain masjid sebenarnya telah berkembang pula lembaga-lembaga pendidikan Islam lainnya baik yang bersifat formal maupun non-formal, lembaga-lembaga ini 
berkembang terus bersamaan dengan tumbuh dan berkembangnya bentuk-bentuk lembaga pendidikan baik non formal maupun formal yang semakin luas. Di antara lembaga-lembaga pendidikan Islam yang ada pada masa Dinasti Abbasiyah tersebut adalah:

a) Kuttab

Sebagai lembaga pendidikan dasar. Sewaktu agama Islam diturunkan Allah sudah ada di antara para sahabat yang pandai tulis baca. Kemudian tulis baca tersebut ternyata mendapat tempat dan dorongan yang kuat dalam Islam, sehingga berkembang luas di kalangan umat Islam. Kepandaian tulis baca dalam kehidupan sosial dan politik umat Islam ternyata memegang peranan penting dikarenakan dari awal pengajaran al-Qur'an juga telah memerlukan kepandaian tulis baca, karena tulis baca semakin terasa perlu maka kuttab sebagai tempat belajar menulis dan membaca, terutama bagi anak-anak berkembang dengan pesat.

b) Pendidikan Rendah di Istana

Pendidikan rendah di istana muncul berdasarkan pemikiran bahwa pendidikan itu harus bersifat menyiapkan anak didik agar mampu melaksanakan tugastugasnya kelak setelah ia dewasa. Atas pemikiran tersebut khalifah dan keluarganya serta para pembesar istana lainnya berusaha menyiapkan pendidikan rendah ini agar anak-anaknya sejak kecil sudah diperkenalkan dengan lingkungan dan tugas-tugas yang akan diembannya nanti (Zuhairini, 1985, p. 92).

c) Toko-Toko Kitab

Perkembangan ilmu pengetahuan dan kebudayaan Islam yang semakin pesat terus diikuti dengan penulisan kitab-kitab dalam berbagai cabang ilmu pengetahuan, maka berdirilah toko-toko kitab. Pada mulanya toko-toko tersebut berfungsi sebagai tempat berjual beli kitab-kitab yang ditulis dalam berbagai ilmu pengetahuan yang berkembang pada masa itu, mereka membelinya dari para penulisnya kemudian menjualnya kepada siapa yang berminat untuk mempelajarinya.

d) Rumah-Rumah Para Ulama

Rumah-rumah ulama juga memainkan peranan penting dalam mentransmisikan ilmu agama dan pengetahuan umum. Pelaksanaan kegiatan belajar di rumah pernah terjadi pada awal permulaan Islam, Rasulullah SAW misalnya pernah menggunakan rumah al-Arqam (Dar al-Arqam) bin Abi al-Arqam sebagai tempat belajar dan mengajar tentang dasar-dasar agama yang baru serta membacakan ayat-ayat al-Qur'an yang diturunkan. Dan pada masa Abbasiyah di antara rumah-rumah para ulama yang digunakan sebagai lembaga pendidikan, rumah yang sering digunakan untuk kegiatan ilmiah adalah rumah al-Rais ibn Sina; sebagian ada yang membaca kitab al-Syifa' dan sebagian lain membaca kitab alQanun (Nata, 2011, pp. 156-157).

e) Majlis atau Saloon Kesusasteraan

Majlis atau saloon kesusasteraan adalah suatu majelis khusus yang diadakan oleh khalifah untuk membahas berbagai ilmu pengetahuan, pada masa ini khususnya pada masa khalifah Harun al-Rasyid majelis sastra ini mengalami kemajuan yang luar biasa, karena khalifah sendiri adalah ahli ilmu pengetahuan yang cerdas, 
sehingga khalifah aktif di dalamnya. Pada masa beliau sering diadakan perlombaan antara ahli-ahli syair, perdebatan antara fukaha dan juga sayembara antara ahli kesenian dan pujangga (Suwito, 2008, p. 103).

f) Badiah

Badiah adalah dusun-dusun tempat tinggal orang-orang Arab yang tetap mempertahankan keaslian dan kemurnian bahasa Arab, bahkan sangat memperhatikan kefasihan berbahasa dengan memelihara kaidah-kaidah bahasanya. Badiah-badiah merupakan sumber bahasa Arab asli dan murni. Oleh karena itu khalifah-khalifah biasanya mengirimkan anak-anaknya ke badiahbadiah ini untuk mempelajari pula syair-syair serta sastra Arab dari sumbernya yang asli. Dan banyak ulama-ulama serta ahli ilmu pengetahuan lainnnya yang pergi ke badiah-badiah dengan tujuan untuk mempelajari bahasa dan kesusasteraan Arab yang asli lagi murni tersebut. Badiah-badiah tersebut menjadi sumber ilmu pengetahuan terutama bahasa dan sastra Arab dan berfungsi sebagai lembaga pendidikan Islam.

g) Rumah Sakit

Untuk memujudkan kesejahteraan para khalifah dan pembesar-pembesar Negara pada masa ini, banyak mendirikan rumah-rumah sakit, rumah-rumah sakit tersebut selain sebagai tempat merawat dan mengobati orang-orang sakit juga berfungsi sebagai tempat untuk mendidik tenaga-tenaga yang berhubungan dengan perawatan dan pengobatan serta tempat untuk mengadakan berbagai penelitian dan percobaan (praktikum) dalam bidang kedokteran dan obatobatan, sehingga berkembanglah ilmu kedokteran dan ilmu obat-obatan atau farmasi. Dengan demikian rumah sakit dalam dunia Islam, juga berfungsi sebagai lembaga pendidikan (Zuhairini, 1985, p. 97).

h) Perpustakaan dan Observatorium

Dalam rangka mengembangkan ilmu pengetahuan yang terjadi pada masa Abbasiyah, maka didirikanlah perpustakaan dan observatorium, serta tempat penelitian dan kajian ilmiah lainnya. Pada lembaga ini, para penuntut ilmu diberikan kesempatan untuk belajar dan mengembangkan ilmu pengetahuannya. Tempat-tempat ini juga digunakan sebagai tempat belajar mengajar dalam arti yang luas, yaitu belajar bukan dalam arti menerima ilmu dari guru sebagaimana yang umumnya dipahami, melainkan kegiatan belajar yang bertumpu pada aktivitas siswa (student centris), seperti belajar dengan cara memecahkan masalah, eksperimen, belajar sambil bekerja (learning by doing), dan inquiry (penemuan). Kegiatan belajar yang demikian ini dilakukan bukan hanya di kelas, melainkan di lembaga-lembaga pusat kajian ilmiah (Nata, 2011, p. 161).

i) Madrasah

Madrasah muncul pada masa Dinasti Abbasiyah sebagai kelanjutan dari pengajaran dan pendidikan yang telah berlangsung di masjid-masjid dan tempat lainnya, selain minat masyarakat yang semakin meningkat untuk mempelajari ilmu pengetahuan juga semakin berkembangnya berbagai ilmu pengetahuan dan keterampilan, dan untuk mengajarkannya diperlukan guru yang lebih banyak, sarana dan prasarana yang lebih lengkap, serta pengaturan administrasi yang lebih teratur. Sehingga melahirkan lembaga formal yaitu madrasah. 


\section{Hasil Terjemahan, Tokoh Intelektual, dan Karya-Karya pada Masa Dinasti Abbasiyah}

Pada abad ke-9 M, dilakukan penerjemahan besar-besaran buku, dalam penerjemahan karya-karya itu, ikut berperan orang-orang Yahudi dan Kristen di samping orang-orang Islam sendiri (Arkoun, 1997, p. 74). Mereka menerjemahkan manuskrip-manuskrip terutama yang berbahasa Yunani dan Persia ke dalam bahasa Arab. Para ilmuan diutus ke Bizantium untuk mencari naskah-naskah Yunani dalam berbagai ilmu terutama filsafat dan kedokteran. Sedangkan untuk perburuan manuskrip di daerah Timur seperti Persia, berupa bidang keilmuan tata negara dan sastra. Sebelum diterjemahkan ke bahasa Arab, naskah yang berbahasa Yunani diterjemahkan dulu ke bahasa Syiria. Hal ini disebabkan karena para penerjemah adalah para pendeta Kristen Syiria yang memahami bahasa Yunani (Abdurrahman, 2003, p. 124).

Pelopor gerakan penerjemahan adalah khalifah al-Mansur, dengan mempekerjakan orang-orang Persia untuk menerjemahkan karya-karya berbahasa Persia, di antaranya: buku tentang Ketatanegaraan (Kalila wa Dimna dan Shindind). Sedangkan manuskrip yang berbahasa Yunani, seperti Logika karya Aristoteles, Almagest karya Ptolemy, Arithmetic karya Nicomachu dari Gerasa, Geometri karya Euclid (Abdurrahman, 2003, p. 124).

Pada masa Harun al-Rasyid, dikenal seorang Yuhanna Yahya ibn Masawayh yang memiliki peran menerjemahkan beberapa manuskrip tentang kedokteran yang dibawa oleh khalifah dari Ankara dan Amorium. Pada masa Makmun dikenal Hunayn ibn Ishaq. (Joannitius, 8o9-873) ia dijuluki "ketua para penerjemah" (sebutan orang Arab), seorang sarjana terbesar dan figur terhormat. Makmun mengangkatnya menjadi pengawas perpustakaan akademinya. Dan bertugas menerjemahkan karya-karya ilmiah, dibantu oleh anaknya Ishaq, dan keponakannya Hubaisy ibal-Hasan yang telah ia latih.

Babak berikutnya setelah adanya era penerjemahan yang berkembang pada Dinasti Abbasiyah adalah babak aktivitas kreatif penulisan karya-karya orisinil. Penulisan karya-karya tersebut melahirkan beberapa tokoh utama yang yang menekuni bidang masing-masing. Pada bidang kedokteran beberapa tokoh yang muncul seperti Ali ibn Sahl Rabban al-Thabari, pertengahan abad kesembilan; Abu Bakr Muh ibn Zakariyya al-Razi (Rhazes, 865-925); Ali ibn al Abbas (w.994); Ibn Sina, 980-1037 (Hitti, 2002, p. 459).

Dalam perkembangan filsafat Islam, peneliti muslim memahami bahwa falsafah merupakan pengetahuan tentang kebenaran dalam arti yang sebenarnya, sejauh hal itu bisa dipahami oleh pikiran manusia. Filsafat dan kedokteran Yunani adalah ilmu yang dimiliki orang Barat, dan orang Arab percaya bahwa al-Qur'an dan teologi adalah rangkuman hukum dan pengalaman agama. Karenanya, kontribusi filsafat, agama, dan kedokteran menjadi tren keilmuan saat itu. Para penulis Arab akhirnya menerapkan kata: falasifah atau hukam (filosof atau sufi) terhadap para filosof yang pemikiran spekulatifnya tidak dibatasi agama; dan Mutakallimun atau Ahl al-kalam (ahli bicara, ahli dialektika) pada orang-orang yang memosisikan sistem pemikirannya di bawah ajaran agama samawi. Ahli membuat proposisi. Seiring perkembangannya, kalam 
berubah maknanya menjadi teologi, dan mutakallimin akhirnya bersinonim dengan teologi, upaya harmonisasi filsafat Yunani dengan Islam dilakukan oleh nama-nama besar dalam bidang filsafat yaitu al-Kindi, al-Farabi, dan Ibn Sina.

\section{PENUTUP}

Dalam sejarah peradaban Islam, periode pertama pemerintahan Bani Abbasiyah dikenal sebagai puncak keemasan dari peradaban Islam. Secara politis, khalifah merupakan seorang tokoh yang betul-betul kuat, dan merupakan pusat kontrol antara politik dan agama. Kemakmuran masyarakat mencapai titik tertinggi, yaitu berhasil menyiapkan landasan perkembangan dunia pendidikan, terutama bagi perkembangan ilmu filsafat, agama, kedokteran, dan berbagai macam ilmu pengetahuan. Kelahiran tokoh-tokoh intelektual seperti al-Kindi, al-Farabi, Ibn Sina, dan berbagai tokoh intelektual lainnya telah mewarnai beragam ilmu pengetahuan di dunia sampai saat ini.

Catatan sejarah pada masa Dinasti Abbasiyah telah menunjukkan, betapa banyaknya Dinasti ini melahirkan para tokoh-tokoh intelektual Islam yang terkenal hingga sekarang. Kemajuan yang ada pada Dinasti Abbasiyah juga tidak terlepas dari stabilitas politik dan kemakmuran ekonomi kerajaan. Pusat kekuasaan Abbasiyah berada di Baghdad. Daerah ini tertumpu pada pertanian dengan sistem irigasi dan kanal di sungai Eufrat dan Tigris yang mengalir sampai Teluk Persia. Perdagangan juga menjadi tumpuan kehidupan masyarakat Baghdad.

Kemajuan Dinasti Abbasiyah begitu pesat dan sangat beragam. Bait al-Hikmah adalah contoh bahwa kekayaan literasi dan ilmu pengetahuan menguasai negeri ini. Pusat ilmu pengetahuan dunia berada pada genggaman masyarakat Islam. Puncak keemasan Dinasti Abbasiyah utamanya berada pada masa khalifah Harun al-Rasyid, dan juga terletak pada masa khalifah al-Makmun yang merupakan seorang putra dari khalifah Harun al-Rasyid sendiri. Setelah berabad-abad lamanya, hingga saat ini masih dapat dijumpai warisan ilmu pengetahuan oleh Dinasti Abbasiyah tersebut. Dinasti Abbasiyah berhasil memegang kekuasaan kekhalifahan selama tiga abad, mengkonsolidasikan kembali kepemimpinan gaya Islam, dan menyuburkan ilmu pengetahuan, serta pengembangan budaya Timur Tengah. Tetapi pada tahun 940 kekuatan kekhalifahan menyusut ketika orang-orang non-Arab, khususnya orang Turki (dan kemudian diikuti oleh Mamluk di Mesir pada pertengahan abad ke-13), mulai mendapatkan pengaruh dan mulai memisahkan diri dari kekhalifahan.

\section{REFERENSI}

Abdurrahman, D. (2003). Sejarah Peradaban Islam: Masa Klasik Hingga Modern. Yogyakarta: LESFI.

Arkoun, L. G. M. (1997). Islam Kemarin dan Hari Esok. (A. Mohammad, Trans.). Bandung: Pustaka.

Hasan, I. (1989). Sejarah dan Kebudayaan Islam. Yogyakarta: Kota Kembang.

Hitti, P. K. (2002). History of The Arabs. (R. C. L. Y. \& D. S. Riyadi, Trans.). Jakarta: PT Serambi Ilmu Semesta. 
Karim, M. A. (2009). Sejarah Pemikiran dan Peradaban Islam. Yogyakarta: Pustaka Book Publisher.

Nata, A. (2011). Sejarah Pendidikan Islam. Jakarta: Kencana.

Nizar, S. (2009). Sejarah Pendidikan Islam, Menelusuri Jejak Sejarah Pendidikan Era Rasulullah sampai Indonesia. (S. Nizar, Ed.). Jakarta: Kencana Prenada Media Grup.

Suwito. (2008). Sejarah Sosial Pendidikan Islam. Jakarta: Kencana.

Syukur, F. (2009). Sejarah Peradaban Islam. Semarang: PT Pustaka Rizki Putra.

Yatim, B. (2008). Sejarah Peradaban Islam. Jakarta: PT. RajaGrafindo Persada.

Zuhairini, M. K. (1985). Sejarah Pendidikan Islam. Jakarta: Departemen Agama.

Majalah As-Sunnah Edisi 7 Tahun XV 1432 H/2011 M. Diakses pada 20/o4/2019. 